\title{
Atopic Dermatitis, food allergy and dietary interventions. A tale of controversy
}

\author{
Dermatite atópica, alergia alimentar e intervenções dietéticas.
}

Um conto de controvérsias

\author{
George V. Guibas ${ }^{1}$ \\ Michael Makris ${ }^{2}$ \\ Catherine Chliva \\ Stamatios Gregoriou ${ }^{3}$ \\ Dimitris Rigopoulos ${ }^{4}$
}

DOI: http://dx.doi.org/10.1590/abd1806-4841.20132072

\begin{abstract}
Atopic Dermatitis has long been a controversial entity in regard its relationship to food allergy. Indeed, inter-discipline disparity in the way dermatologists and allergologists perceive the food allergy/atopic dermatitis interplay, hampers the design of concise therapeutic strategies and conveys conflicting messages to the patients. Within this conceptual frame, food exclusion regimes are rendered a contentious option. On the basis of this acknowledgment, we opted to put the emphasis on the discrepant perceptions surrounding such therapeutic regimes and to share our view pertaining to their appropriate implementation.
\end{abstract}

Keywords: Dermatitis, atopic; Diet; Food hypersensitivity

Resumo: A Dermatite atópica é uma entidade que há tempos tem levantado controvérsias quanto à sua relação com a alergia alimentar. Com efeito, a disparidade interdisciplinar que existe na maneira em que dermatologistas e alergologistas percebem a interação entre alergia alimentar/dermatite atópica prejudica a elaboração de estratégias terapêuticas mais exatas e transmite mensagens conflitantes aos pacientes. Nessa estrutura conceitual, regimes de exclusão alimentar são considerados uma alternativa discutível. Com base nessa percepção, optamos por colocar ênfase nas percepções controvertidas ligadas a tais regimes terapêuticos e compartilhar nossa visão quanto à sua implementação adequada.

Palavras-chave: Dermatite atópica, Dieta; Hipersensibilidade alimentar

\section{INTRODUCTION}

Atopic dermatitis (AD) is a chronic inflammatory skin disease characterized by pruritic eczematous lesions. $\mathrm{AD}$ is elicited by various stimuli including inhaled/food allergens, irritating substances and infectious microorganisms. ${ }^{1}$ Among food allergens, cow's milk, hens' eggs, wheat, soy, tree nuts and peanuts are the most commonly reported culprits. ${ }^{2}$ Nevertheless, a causal relationship between food allergy and AD is controversial. ${ }^{1}$ Indeed, a dichotomy exists as to whether the increased prevalence of food allergy in $\mathrm{AD}$ patients is a parallel occurrence rather than an AD contributing factor. ${ }^{1,3}$ Furthermore, even though food allergy is increasingly implicated in cer- tain forms of $\mathrm{AD}$, food exclusion is not a familiar concept in the dermatological setting and it is generally frowned upon. ${ }^{4,5}$

Impelled by this intra-field inconsistency we opted to assess the exposure of dermatologists and allergologists to pertinent information. To this end, we performed a Pubmed search using combination of the key words: "Atopic dermatitis", "eczema" and "food allergy" in six reputable scientific journals of dermatological orientation (Journal of the European Academy of Dermatology and Venereology, Journal of the American Academy of Dermatology, British Journal of Dermatology, Journal of Investigational Dermatology, Clinical and

\footnotetext{
Received on 20.08.2012.

Approved by the Advisory Board and accepted for publication on 11.09.2012.

Work performed at the "Attikon" University Hospital - Xaidari, Greece.

Conflict of interest: None

Financial support: None

MD - Allergy Unit, Attikon Hospital - Xaidari, Greece.

MD, PhD - Allergy Unit, Attikon Hospital - Xaidari, Greece.

MD, PhD - 2nd Dpt. of Dermatology and Venereology, Medical School, University of Athens, "Attikon" University Hospital - Athens, Greece.

AdHoc - AdHoc University of Athens, Department of Dermatology, Attikon Hospital - Xaidari, Greece. 
Experimental Dermatology, Experimental Dermatology) and six of allergologic interest (Journal of Allergy and Clinical Immunology; Clinical and Experimental Allergy; Allergy; Annals of Allergy, asthma and immunology; International Archives of Allergy and Immunology; Clinical and Molecular Allergy). Our search in the dermatological journals returned 40 reports; 17 were irrelevant and 11 were case reports/short communications/letters to the editor. The articles collectively conveyed a rather negative message towards food exclusion diets. In sharp contrast, our search in the allergologic literature yielded 378 reports with the vast majority of them assuming a positive stance towards food interventions. From this perspective, although allergy-oriented journals publish numerous food allergy related reports ex vi termini, it strikes us as odd that the specialists primarily treating $\mathrm{AD}$ patients, i.e. dermatologists, are exposed to considerably limited relevant information.

Therefore our aim is to emphasize such controversial cross-discipline perceptions and to convey our views pertaining to the appropriate implementation of food exclusion regimes.

\section{DISCUSSION}

The pathophysiology of $\mathrm{AD}$ remains unclear. ${ }^{1}$ As there is no definite cure, patients often undertake avoidance of fish, seafood, beef, eggs and dairy products without medical supervision, hence triggering malnutrition-related pathology. ${ }^{6}$ Furthermore, various allergy tests are readily available in pharmacies and laboratories, where they are performed outside their medical context. Therefore, a false interpretation may erroneously drive a patient into obstinate avoidance of certain foodstuffs, a decision further instigated by conflicting cross-discipline medical guidance. ${ }^{4} \mathrm{~A}$ recent Cochrane review questioning the efficacy of food exclusion diets - except for eggs - in unselected populations, further perplexes their evaluation. ${ }^{7}$ Nevertheless, it does not conclusively refute dietary interventions in selected patients. Indeed, the ADaggravating capacity of food intake in certain clusters of patients, has been well documented. ${ }^{8}$

In regard to when such measures should be implemented, reports of consistent correlation of food intake with $\mathrm{AD}$ exacerbations are invaluable.
Suspicion of a certain food should lead to skin-prick tests (SPTs) and serum specific IgE determination (RAST) to assess type I reactions or atopy patch tests (ATP) for type IV reactions - albeit usefulness of the later is controversial. ${ }^{9}$ If both history and diagnostic tests furnish information suggestive of food allergy involvement, dietary intervention could be undertaken. However, in vivo or in vitro identification of $\operatorname{IgE}$ sensitization to a certain food should not include barring it from the patients diet in the absence of indications of clinical relevance. Furthermore, disease abatement during an elimination diet could be coincidental, as $\mathrm{AD}$ runs a course of relapses and remissions. On the basis of this acknowledgment, symptoms should be reproduced following an oral food challenge (OFC). Double-blind-placebo-controlled OFCs comprise the cornerstone of diagnosis but their considerable cost and labor-heavy nature impede their routine use in favor of open-label or single-blind OFCs. If the medical history is inconclusive albeit nonspecific suspicion arises, an oligoantigenic diet, i.e. administration of low-danger foodstuffs, can be implemented. Duration of the diet should be limited and -if remission ensues- foods should be reintroduced gradually in order for an $\mathrm{AD}$ trigger to be identified

A link between food allergy and AD, albeit possible in infants, is questionable in adults. ${ }^{10}$ Furthermore, in adults, ingestion of histamine-releasing foods can confound accurate diagnosis of true food allergy. Nevertheless, AD aggravation by pollenassociated cross allergens and by non-typical mechanisms (f.e. food additives) should not be readily dismissed in this age group.

\section{CONCLUDING REMARKS}

Most of the AD cases under self-imposed dietary manipulations most likely face malnutrition issues and uncontrolled disease due to poor skin care. This situation has the potential to bias dermatologists into readily dismissing well-designed food exclusion regimes. Within this conceptual frame we emphasize the need for food allergy testing and potential dietary interventions in refractory $A D$ cases, where an topic predisposition is highly suspected. In a broader context, we prompt for allergological consultancy of such patients upon failure of conventional skin treatment. $]$ 


\section{REFERENCES}

1. Getmetti C. Diet and atopic dermatitis. J Eur Acad Dermatol Venereol. 2000;14:439-40.

2. Darsow U, Wollenberg A, Simon D, Taïeb A, Werfel T, Oranje A, et al. European Task Force on Atopic Dermatitis/EADV Eczema Task Force. ETFAD/EADV eczema task force 2009 position paper on diagnosis and treatment of atopic dermatitis. J Eur Acad Dermatol Venereol. 2010;24:317-328.

3. Sampson HA. Food allergy. Part 2: diagnosis management. J Allergy Clin Immunol. 1999;103:981-9.

4. Yuh KY. Food allergy and atopic dermatitis: separating fact from fiction. Semin Cutan Med Surg. 2010;29:72-8.

5. Patel T, Gawkrodger DJ. Food allergy in patients with eczema: immediate symptoms are usual, with nuts and tomatoes the major allergens. J Eur Acad Dermatol Venereol. 2011;25:865-7.

6. Hon KL, Leung TF, Kam WY, Lam MC, Fok TF, Ng PC. Dietary restriction and supplementation in children with atopic eczema. Clin Exp Dermatol. 2006;31:187-91.

7. Bath-Hextall F, Delamere FM, Williams HC. Dietary exclusions for established atopic eczema. Cochrane Database Syst Ver. 2008:CD005203.

8. Sicherer S, Sampson HA. Food hypersensitivity and atopic dermatitis: pathophysiology, epidemiology, diagnosis, and management. J Allergy Clin Immunol. 1999;104:S114-22.

9. Sampson HA, Ho DG. Relationship between food-specific lgE concentrations and the risk of positive food challenges in children and adolescents. J Allergy Clin Immunol. 1997;100:444-51

10. Worm M, Forschner K, Lee HH, Roehr CC, Edenharter G, Niggemann B. Frequency of atopic dermatitis and relevance of food allergy in adults in Germany. Acta Derm Venereol. 2006;86:119-22.
MAILING ADDRESS:

Dimitris Rigopoulos

Allergy Unit "D. Kalogeromitros",

2nd Dpt. of Dermatology and Venereology,

Medical School, University of Athens,

"Attikon" University Hospital, Rimini 1 -Xaidari

12462 - Athens - Greece

E-mail: stamgreg@yahoo.gr

How to cite this article: Guibas GV, Makris M, Chliva C, Gregoriou S, Rigopoulos D. Atopic Dermatitis, food allergy and dietary interventions. A tale of controversy. An Bras Dermatol. 2013;88(5):839-41. 